\title{
Long-Term Sequelae of Frostbite-A Scoping Review
}

\author{
Ivo B. Regli ${ }^{1,2, *(\mathbb{D}}$, Giacomo Strapazzon ${ }^{1,3} \mathbb{D}$, Marika Falla ${ }^{1,4} \mathbb{D}$, Rosmarie Oberhammer ${ }^{5}(\mathbb{D})$ and \\ Hermann Brugger ${ }^{1,3}$ (D)
}

1 Institute of Mountain Emergency Medicine, Eurac Research, 39100 Bolzano, Italy; Giacomo.strapazzon@eurac.edu (G.S.); marika.falla@unitn.it (M.F.); Hermann.brugger@eurac.edu (H.B.)

2 Department of Anaesthesia and Intensive Care, "F. Tappeiner" Hospital, 39012 Merano, Italy

3 Department of Anaesthesia and Intensive Care, Medical University Innsbruck, 6020 Innsbruck, Austria

4 Center for Mind/Brain Sciences, University of Trento, 38123 Rovereto, Italy

5 Department of Anaesthesia and Intensive Care, Hospital of Brunico, 39031 Brunico, Italy; rosmarie.oberhammer@sabes.it

* Correspondence: ivo.regli@eurac.edu; Tel.: +39-0471-055-863

check for

updates

Citation: Regli, I.B.; Strapazzon, G.; Falla, M.; Oberhammer, R.; Brugger, H. Long-Term Sequelae of Frostbite-A Scoping Review. Int. J. Environ. Res. Public Health 2021, 18, 9655. https:// doi.org/10.3390/ijerph18189655

Academic Editor: Paul B. Tchounwou

Received: 31 July 2021

Accepted: 6 September 2021

Published: 14 September 2021

Publisher's Note: MDPI stays neutral with regard to jurisdictional claims in published maps and institutional affiliations.

Copyright: (c) 2021 by the authors. Licensee MDPI, Basel, Switzerland. This article is an open access article distributed under the terms and conditions of the Creative Commons Attribution (CC BY) license (https:// creativecommons.org/licenses/by/ $4.0 /)$.

\begin{abstract}
Frostbite is tissue damage caused by freezing temperatures and constitutes an important cause of morbidity in cold climate zones and high altitude. The direct effects of sub-zero temperatures lead to tissue freezing, electrolyte shifts and $\mathrm{pH}$ alterations, microvascular damage, and eventually to cell death. Upon rewarming, inflammatory reperfusion injury and thrombosis may lead to further tissue damage. Several studies and various case reports show that many patients suffer from longterm sequelae such as vasomotor disturbances (associated with susceptibility to refreezing), and neuropathic and nociceptive pain, as well as damage to skeletal structures. There are still many uncertainties regarding the pathophysiology of these sequelae. It has been shown that the transient receptor potential channel (TRP) family plays a role in cold allodynia. Botulinum Toxin type A (BTX-A) injections have been reported to be beneficial in vasomotor and neuropathic disturbances secondary to frostbite. Epidural sympathetic block has been used for short-term treatment of frostbite induced chronic pain. Furthermore, amitriptyline, gabapentinoids, and duloxetine may have some benefits. Frostbite arthritis clinically resembles regular osteoarthritis. In children there is a risk of epiphyseal cartilage damage leading to bone deformities. Despite some promising therapeutic concepts, the scarcity of data on frostbite long-term sequelae in the literature indicates the need of more in-depth studies of this pathology in all its aspects.
\end{abstract}

Keywords: frostbite; cold injury; pathophysiology; neuropathic pain; nociceptive pain; arthritis; vasospasm

\section{Background}

Frostbite is defined as tissue-freezing caused by heat loss sufficient to cause ice-crystal formation in superficial or deep tissue [1]. The severity of frostbite injury depends on environmental temperature, wind chill factor, and length of exposure [2]. Due to their exposed and peripheral anatomical position, frostbite mainly affects distal upper and lower extremities, ears, nose, and cheeks [3]. There is a wide spectrum of clinical presentation of frostbites, ranging from injuries that resolve completely without any consequences, to injuries that result in major limb amputation [4]. However, even without significant tissue loss, patients may suffer from long-term sequelae after having suffered a frostbite injury. These can include vasomotor disorders, neuropathic and nociceptive pain, and frostbite arthritis [5]. Thus far, long-term sequelae of frostbite have been little explored.

This review aims to elucidate the rather neglected aspect of long-term sequelae of frostbite-its epidemiology, its pathophysiology, and its treatment. 


\subsection{Epidemiology}

There are no data on the overall incidence of frostbite. Thus far, the oldest recorded frostbite injury was found in the little toe of a 5300 years-old mummified body found on a glacier in the Italian Alps [6]. In military medicine, frostbite has been a significant factor of morbidity since ancient times, e.g., during the crossing of the Alps of Hannibal's soldiers [4]. In the early 19th century, Dr. Dominique Jean Larrey, Napoleon Bonaparte's Surgeon-inChief, wrote the first systematic report on frostbite injuries and their treatment [7]. In World War II, allied forces recorded 91,000 cases of frostbite, while German troops reported 46,000 cases [8].

Besides military personnel, other populations at risk of frostbite include psychiatric patients, homeless people, and people with a history of substance abuse [9]. A lack of adequate protection from the cold, either due to a lack of shelter or protective behaviours, is an important additional risk factor. A Canadian study reported that the most important predisposing factors for frostbite in Saskatchewans were alcohol consumption (46\% of patients) and history of psychiatric illness (17\% of patients) [10].

With the increase in people enjoying recreational activities in cold environments, and an increased accessibility to these environments for people with limited experience and/or inadequate preparation and equipment, the importance of frostbite has become more prevalent in such populations in recent years; additional risk factors include dehydration, high-altitude, and hypoxia, and pre-existing conditions such as peripheral vascular disease, diabetes mellitus, and Raynaud's disease [11]. Of 24,079 climbers on Denali, Alaska, USA, between 1992 and 2011, 831 needed medical assistance, of which 171 were diagnosed with frostbite [12]. Out of 2941 patients treated in the medical facilities on the Everest base camp, Nepal, from 2003-2012, 77 were diagnosed with frostbite [13]. In the Teheran region, Iran, the incidence of frostbite in mountaineers was $366 / 1000$ persons per year, with $83 \%$ being described as first grade injuries [14].

Many of the subjects that had suffered from frostbite complained about long-term sequelae [15-22]. Due to short periods of follow-up and the fact that most case reports in the literature do not address long-term sequelae, it is difficult to indicate an exact incidence of these conditions.

\subsection{Pathophysiology}

Continued cold exposure of tissue leads to rapid vasoconstriction of the skin, which leads to further cooling and vasoconstriction of the subcutaneous tissue [23] (Figure 1). While cooling, human skin undergoes cycles of approximatively five to ten minutes, in which vasoconstriction is followed by vasodilatation, an adaptive response known as "Hunting reaction" [24]. Eventually, functional impairment of the neurons leads to loss of cutaneous sensation [3]. In the case of further cooling, vascular contents increase in viscosity and eventually the blood supply to the affected tissue gets shunted away to maintain core temperature, which in turn favours further tissue cooling.

While wind increases the speed of cooling (an effect known as "wind chill"), it does not affect the skin temperature [25]. Once freezing starts, extracellular and intracellular ice-crystal formation begins, which alters the osmotic gradient leading to electrolyte shifts, $\mathrm{pH}$ alterations, intracellular dehydration, and hyperosmolality, followed by harm to the cellular integrity of the affected subcutaneous tissue [26-28]. It has been proposed that a rapid-onset freezing injury (i.e., due to a higher temperature gradient and/or induced by a material with a high thermal conductivity) may initially lead to more intracellular ice-crystal formation while a slower-onset injury may lead initially to predominantly extracellular ice-crystal formation [29]. The damage to the microvascular endothelium of the affected tissue results in disruption of the microcirculation, leading to ischaemia and necrosis. After prolonged exposure to freezing temperature, ice-crystals increase in size, which directly damages cell membranes and extracellular structures. Of note, cartilage, especially epiphyseal cartilage, has been described to be particularly susceptible to frostbite injury [3]. 


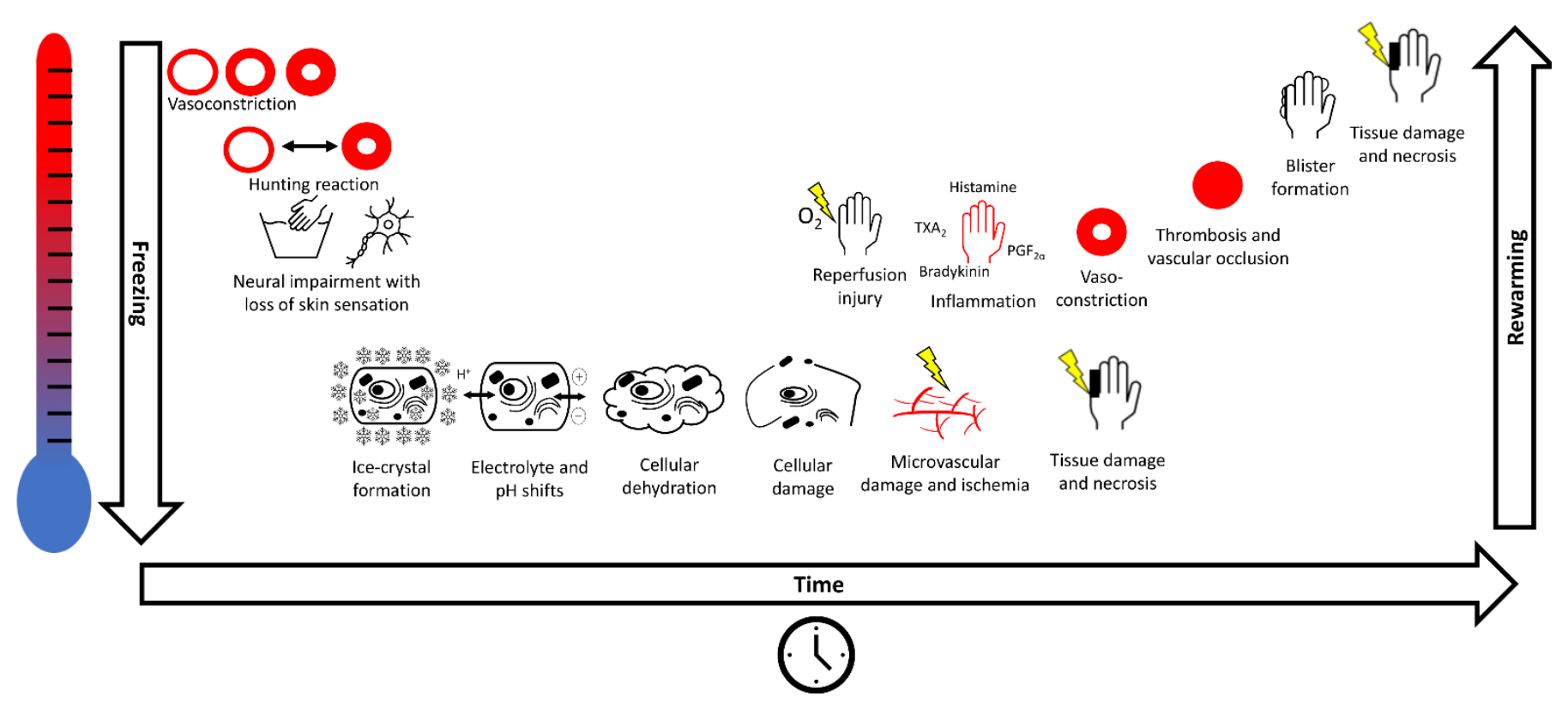

Figure 1. Pathophysiological cascade of frostbite. Cooling of the skin leads to vasoconstriction and to cycles of intermittent vasodilation and vasoconstriction, known as the "Hunting reaction". Eventually neuronal impairment occurs with loss of sensation. Skin freezes with formation of extracellular ice-crystals that leads to electrolyte and pH shifts, cellular dehydration, and cell damage. Damage to the microvasculature results in ischaemia, tissue damage and necrosis, worsening over time. When skin is rewarmed, injury leads to inflammation, vasoconstriction, thrombosis, vascular occlusion, blister formation and eventually to tissue damage and necrosis.

Upon rewarming of frozen tissue, reperfusion injury with the generation of radical oxygen species (ROS) leads to an inflammatory response [30]. Data from burn models showed that prostaglandins, thromboxanes, bradykinin, and histamine are involved in oedema formation, endothelial injury, and subsequent arrest of dermal blood flow (Jackon's zone of stasis) [31-38]. The presence of prostaglandin $\mathrm{F}_{2 \alpha}$ and thromboxane $\mathrm{B}_{2}$ (a stable metabolite of thromboxane $\mathrm{A}_{2}$ ), molecules that are known to be involved in vasoconstriction, platelet aggregation, and thrombosis, in both frostbite and burn injury blister fluid has been reported, indicating similar mechanisms of injury [39,40]. Subsequently, intravascular coagulation and oedema formation further sustain the reperfusion injury, potentially leading to showers of microthrombi damaging the microvasculature, and thrombus formation in larger vessels $[3,39]$. The outcome of frostbite injury depends on the degree of microvascular damage in any given tissue. Refreezing and subsequent rewarming, and thus multiple cycles of the pathophysiological cascade depicted in Figure 1, are related with a worse outcome.

Following acute pathology, frostbite long-term sequelae are associated with vasomotor dysfunction-in particular, vasospasm leading to circulatory disturbances, resulting in chronic pain and cold hypersensitivity. Also, cold-induced nerve damage is linked to neuropathic pain and ischemic neuritis. Furthermore, cold-induced arthritis is an important chronic condition that occurs in patients with a history of cold injury, which often only appears months or years later.

\subsection{Classification}

Frostbite classification is often performed using a scheme analogous to the classification of burn injuries, categorizing injuries in four different degrees [4]. In 2001, Cauchy et al. retrospectively reinterpreted the extent of the initial lesions of 70 patients with frostbite injuries, evaluated after rapid $(1 \mathrm{~h})$ rewarming of the tissue in warm $\left(38^{\circ} \mathrm{C}\right)$ water, and final amputation results. Based on these data and data obtained from isotopic bone scans, they proposed an alternative classification scheme based on the clinical appearance and 
anatomical extension of the frostbite lesion using the following grades: first grade: absence of initial lesion; second grade: initial lesion on distal phalanx; third grade: initial lesion on intermediate or proximal phalanx; 4th grade: initial carpal/tarsal lesion [41]. A comparison of the two classification systems is depicted in Table 1. Due to the still-sparse data available, there is currently no uniform classification of long-term sequelae of frostbite.

Table 1. Classification of frostbite.

\begin{tabular}{|c|c|c|c|c|}
\hline \multicolumn{2}{|c|}{ Classification Proposed by Cauchy et al. } & \multicolumn{3}{|c|}{ Classification Analogous to Burn Injury } \\
\hline & $\begin{array}{l}\text { Extent of Initial Lesion } \\
\text { Immediately after } \\
\text { Rewarming }\end{array}$ & & Lesion Characteristics * & $\begin{array}{l}\text { Time to Onset } \\
\text { After Rewarming }\end{array}$ \\
\hline $\begin{array}{l}\text { first } \\
\text { Grade }\end{array}$ & Absence of initial lesion & $\begin{array}{c}\text { first } \\
\text { Degree }\end{array}$ & $\begin{array}{l}\text { Partial skin freezing with: } \\
\text { Erythema, oedema } \\
\text { Skin desquamation }\end{array}$ & $\begin{array}{l}2-3 h \\
5-10 \text { days }\end{array}$ \\
\hline $\begin{array}{l}\text { second } \\
\text { Grade }\end{array}$ & Initial lesion on distal phalanx & $\begin{array}{l}\text { second } \\
\text { Degree }\end{array}$ & $\begin{array}{l}\text { Full thickness skin freezing with: } \\
\text { Clear blister formation } \\
\text { Intensive pain }\end{array}$ & $\begin{array}{l}12-24 \mathrm{~h} \\
3-10 \text { days }\end{array}$ \\
\hline $\begin{array}{l}\text { third } \\
\text { Grade }\end{array}$ & $\begin{array}{l}\text { Initial lesion on intermediate } \\
\text { or proximal phalanx }\end{array}$ & $\begin{array}{l}\text { third } \\
\text { Degree }\end{array}$ & $\begin{array}{l}\text { Subcutaneous freezing with: } \\
\text { Haemorrhagic blister formation } \\
\text { Skin necrosis }\end{array}$ & $\begin{array}{c}12-24 \mathrm{~h} \\
5 \text { days }-5 \text { weeks }\end{array}$ \\
\hline $\begin{array}{l}\text { fourth } \\
\text { Grade }\end{array}$ & Initial carpal/tarsal lesion & $\begin{array}{l}\text { fourth } \\
\text { Degree }\end{array}$ & $\begin{array}{l}\text { Freezing deeper than the subcutis with: } \\
\text { Cyanotic and insensitive tissue } \\
\text { Tissue mummification }\end{array}$ & $\begin{array}{l}\text { Immediately } \\
\text { up to } 3 \text { months }\end{array}$ \\
\hline
\end{tabular}

${ }^{*}$ Lesion characteristics for a specific degree include those described plus those of all the lower degrees.

Comparison of the classification system proposed by Cauchy et al. [41] versus the traditional system that is based on the classification of burn injuries [4,42].

\subsection{Management}

Detailed descriptions of the broad spectrum of therapeutic options and recommendations for optimal frostbite treatment are published elsewhere (e.g., [1]). Briefly, frostbitten body parts should be protected from further cooling and mechanical damage. Since damage deteriorates during tissue freezing and rewarming, refreezing of tissue should be strictly avoided. In-field rewarming should only be considered if the risk of refreezing is negligible. Pain control should be achieved using nonsteroidal anti-inflammatory drugs (NSAID) and/or opioids. The need for hospital admission or outpatient treatment of frostbite patients must be assessed based on the severity of injury, comorbidities, medical history, and the need for in-hospital interventions (i.v. medication, radiology, surgery). Of note, during the first $24 \mathrm{~h}$, the transfer of patients to a facility capable of administering thrombolysis, and, during the first $72 \mathrm{~h}$, hospital admission for iloprost treatment, should be considered. Healing of frostbite can take from a few days up to several months and in some instances amputation of nonviable tissue is necessary $[43,44]$. For the management of frostbite long-term sequelae, Botulinum toxin has been proposed as a treatment for neuropathic and vasomotor difficulties [45]. Amitryptiline, gabapentinoids, duloxetine, and topical capsaicin or lidocaine, as well as epidural sympathectomy, is thought to be beneficial in chronic pain [46-49].

\section{Methods}

In this review, cases regarding long-term sequelae from frostbite were identified and selected through a scoping literature review. This method was chosen because it was considered the most appropriate for identifying and mapping the available evidence on this topic. We followed to the Prisma-ScR checklist and scoping review guidelines (Figure 2) [50]. We did not establish or publish an a priori protocol for this study, and to our knowledge, none currently exists. For the purposes of this review, included cases conformed to all the 
following criteria: (1) cold injury from freezing temperatures, (2) $\geq 1$ chronic ailment from cold injury, and (3) the possibility to retrieve a full-text version of the article online.

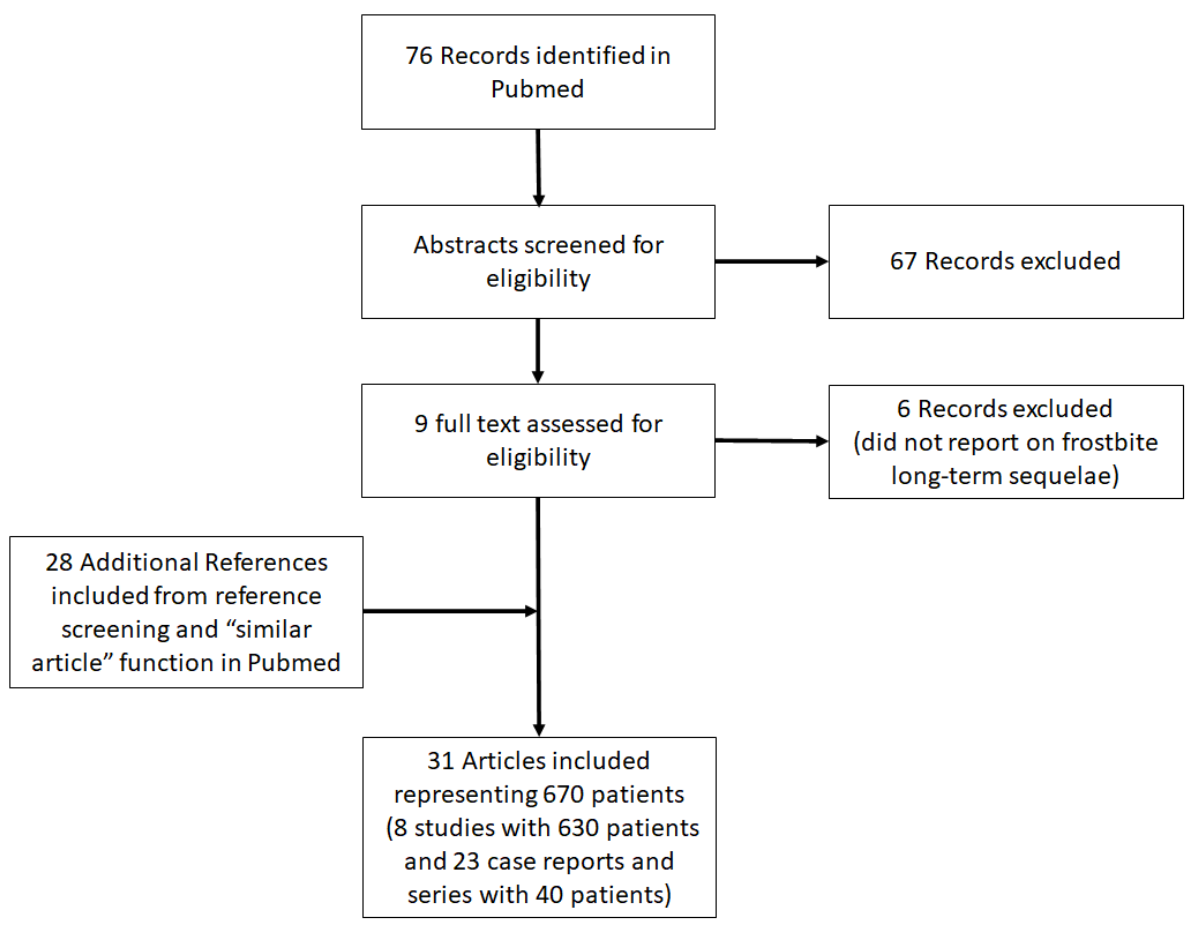

Figure 2. Preferred Reporting Items for Systematic Reviews and Meta-Analyses (PRISMA-ScR) flow chart for reference/literature selection [50].

Literature published until 12 July 2021 was searched in PubMed using the following search terms: "'long term*"[All Fields] OR "long-term*"[All Fields] OR "chronic*"[All Fields]) AND ("frostbite*"[All Fields] OR “cold injur*"[All Fields] OR "cold-injur*"[All Fields]) AND ("aftereffect" Fields] OR "outcome*"[All Fields] OR "result*" [All Fields] OR "ramification*"[All Fields] OR "implication*"[All Fields] OR "repercussion*"[All Fields]). We did not limit the search to a specific article type, as long as the article was published in a peer-reviewed journal. We then used two additional searching techniques to increase the number of relevant articles. By entering the title of each article searched in the search field, we took advantage of the "similar articles" search option in PubMed. In addition, we searched the bibliography of retrieved articles for additional articles not found in the original searches. We only included articles in English. One author (IR) conducted the literature review and created the database. All reports that described any long-term effects of frostbite were considered, regardless of the level of detail. Articles not clearly distinguishing between frostbite and other pathologies (e.g., non-freezing cold injury) were excluded. Articles were categorized as either "study" or "case report/series". We considered an article a study if data from various patients were synthesized into a tangible conclusion (e.g., the prevalence of a certain long-term sequelae). Data from studies are represented in a table depicting the population and follow-up timing, the grade or degree of frostbite, and the frequencies of patients suffering from long-term sequelae. Articles that described the signs or symptoms and possible treatments and outcomes of individual patients we considered case reports/series. Data from case reports/series are represented in a supplementary table including the patient's age, grade/degree of frostbite, sex, location of the injury, time since the initial frostbite injury, signs, and symptoms, as well as treatment and outcome. 


\section{Results}

The database search identified a total of 76 references (Figure 2). A total of 67 references were excluded after reading the title and abstract and 9 were retrieved for further evaluation. Of these, 6 studies were excluded, because they did not report on long-term sequelae after frostbite injury. Following the selection process and additional reference screening, 8 studies plus 23 other case reports were included in the scoping review. Table 2 shows the results of 8 studies regarding long-term sequelae of frostbite.

Table 2. Studies reporting frostbite long-term sequelae.

\begin{tabular}{|c|c|c|c|}
\hline Article & Population and Follow Up Timing & $\begin{array}{l}\text { Frostbite } \\
\text { Grade/Degree }\end{array}$ & Long-Term Sequelae \\
\hline $\begin{array}{l}\text { Norheim et al., } \\
2018[15]\end{array}$ & $\begin{array}{c}\text { Self-reported data of } 397 \text { Norwegian } \\
\text { soldiers in } 2017 \text { having suffered frostbite } \\
\text { from } 2010-2014\end{array}$ & $1-2$ & $\begin{array}{c}70 \% \text { with long-term sequelae } \\
21 \% \text { unable to work and undertake usual } \\
\text { leisure activities }\end{array}$ \\
\hline $\begin{array}{l}\text { Carlsson et al., } \\
\quad 2014[16]\end{array}$ & $\begin{array}{l}\text { Self-reported data of } 12 \text { patients; } \\
4 \text { patients with hand frostbite, } 6 \text { patients } \\
\text { with feet frostbite, and } 2 \text { patients with } \\
\text { hand and feet frostbite; hand frostbite } \\
\text { was followed-up after } 4 \text { month and } \\
4 \text { years, foot frostbite only after } 4 \text { years }\end{array}$ & $1-2$ & $\begin{array}{c}4 \text { months after frostbite of the hands }(n=6) \text { : } \\
100 \% \text { with discomfort when exposed to cold } \\
67 \% \text { with cold sensation } \\
67 \% \text { with white fingers } / \text { toes } \\
4 \text { years after frostbite of the hands }(n=6) \text { : } \\
100 \% \text { with discomfort when exposed to cold } \\
83 \% \text { with cold sensation } \\
17 \% \text { with white fingers } / \text { toes } \\
4 \text { years after frostbite of the feet }(n=8) \text { : } \\
89 \% \text { with discomfort when exposed to cold } \\
100 \% \text { with cold sensation } \\
100 \% \text { with white fingers } / \text { toes }\end{array}$ \\
\hline $\begin{array}{l}\text { Koljonen et al., } \\
\text { 2004 [17] }\end{array}$ & $\begin{array}{l}\text { Self-reported data form } 14 \text { patients with } \\
\text { frostbite during the previous } 7 \text { years }\end{array}$ & Not specified & $\begin{array}{l}15 \% \text { with daily, intolerable pain } \\
50 \% \text { chronic pain } \\
50 \% \text { with limitations in their social life } \\
36 \% \text { with poor emotional well being }\end{array}$ \\
\hline $\begin{array}{l}\text { Ervasti et al., } \\
\quad 2000[18]\end{array}$ & $\begin{array}{l}\text { Clinical examination of } 30 \text { patients with } \\
\text { frostbite } 4-11 \text { years earlier }\end{array}$ & 2 & $\begin{array}{c}63 \% \text { with sequelae of any kind } \\
66 \% \text { with increased tendency for vasospasm } \\
53 \% \text { with hypersensitivity to cold } \\
40 \% \text { with numbness of fingers } \\
33 \% \text { with declined sensitivity to touch } \\
13 \% \text { with lowered working ability }\end{array}$ \\
\hline $\begin{array}{l}\text { Arvesen et al., } \\
1996^{*}[19]\end{array}$ & $\begin{array}{l}\text { Clinical examination of } 40 \text { Norwegian } \\
\text { soldiers with frostbite in the previous } \\
21-78 \text { months; } 16 \text { with involvement of } \\
\text { the hands and } 24 \text { with involvement of the } \\
\text { feet }\end{array}$ & $1-3$ & $\begin{array}{c}38 \% \text { with disturbed sense of cold } \\
38 \% \text { with disturbed sense of heat } \\
33 \% \text { skin and nail dystrophia } \\
20 \% \text { with hyperhidrosis } \\
18 \% \text { with reduced light-touch perception } \\
18 \% \text { with reduced pain perceptions } \\
10 \% \text { with reduced blunt-touch perception } \\
8 \% \text { with pain on deep pressure } \% \text { with } \\
\text { paraesthesia } \\
3 \% \text { with reduced muscle power }\end{array}$ \\
\hline
\end{tabular}


Table 2. Cont.

\begin{tabular}{|c|c|c|c|}
\hline Article & Population and Follow Up Timing & $\begin{array}{c}\text { Frostbite } \\
\text { Grade/Degree }\end{array}$ & Long-Term Sequelae \\
\hline $\begin{array}{l}\text { Rosen et al., } \\
1991 *[20]\end{array}$ & $\begin{array}{l}\text { Self-reported data of } 40 \text { Norwegian } \\
\text { soldiers with frostbite at least } 2 \text { years } \\
\text { prior; } 18 \text { with involvement of the } \\
\text { hands and } 28 \text { with involvement of the } \\
\text { feet }\end{array}$ & $1-3$ & $\begin{array}{c}\text { Hands: } \\
100 \% \text { with cold hypersensitivity } \\
50 \% \text { with paraesthesia } \\
61 \% \text { with hypaesthesia } \\
56 \% \text { skin and nail dystrophia } \\
44 \% \text { with pain } \\
6 \% \text { with hyperaesthesia } \\
6 \% \text { with hyperhidrosis } \\
6 \% \text { with arthralgia } \\
\text { Feet: } \\
93 \% \text { with cold hypersensitivity } \\
64 \% \text { skin and nail dystrophia } \\
54 \% \text { with pain } \\
46 \% \text { with paraesthesia } \\
54 \% \text { with hypaesthesia } \\
14 \% \text { with hyperhidrosis } \\
11 \% \text { with hyperaesthesia } \\
7 \% \text { pain when walking } \\
4 \% \text { with arthralgia }\end{array}$ \\
\hline $\begin{array}{l}\text { Taylor et al., } \\
1989 \text { [21] }\end{array}$ & $\begin{array}{l}40 \text { US soldiers examined } 6 \text { months } \\
\text { after frostbite }\end{array}$ & $1-4$ & $\begin{array}{l}65 \% \text { with neurovascular sequelae (cold } \\
\text { sensitivity, paraesthesia, pain, and } \\
\text { hyperaesthesia) } \\
8 \% \text { had to be reassigned to new functions } \\
\text { due to symptom severity }\end{array}$ \\
\hline \multirow{3}{*}{$\begin{array}{l}\text { Blair et al., } \\
1957 \text { [22] }\end{array}$} & \multirow{3}{*}{$\begin{array}{l}\text { Self-reported data of } 97 \text { US soldiers } \\
\text { with frostbite in previous } 4 \text { years; } \\
50 \text { were examined clinically }\end{array}$} & \multirow{3}{*}{$2-4$} & $\begin{array}{c}\text { Self-reported sequelae in winter } \\
71 \% \text { with numbness } \\
70 \% \text { with pain } \\
69 \% \text { with cold feet } \\
58 \% \text { with abnormal colour } \\
53 \% \text { with hyperhidrosis } \\
40 \% \text { with pathology in joints }\end{array}$ \\
\hline & & & $\begin{array}{c}\text { Self-reported sequelae in summer } \\
31 \% \text { with numbness } \\
45 \% \text { with pain } \\
24 \% \text { with cold feet } \\
31 \% \text { with abnormal colour } \\
78 \% \text { with hyperhidrosis } \\
25 \% \text { with pathology in joints }\end{array}$ \\
\hline & & & $\begin{array}{l}\text { Sequelae detected on physical examination } \\
58 \% \text { with abnormal nails } \\
48 \% \text { with abnormal colour } \\
42 \% \text { with hyperhidrosis } \\
28 \% \text { with joint stiffness }\end{array}$ \\
\hline
\end{tabular}

* Studies about the same subjects.

Among 493 patients from five studies in which long-term sequalae could be clearly attributed to individuals, 341 were affected $(69 \%)[15-18,21]$. Three of seven studies reported long-term sequelae in 56 civil patients and four studies in 574 military persons. The incidence and type of long-term sequelae (i.e., neuropathy-related signs and symptoms) were similar between different studies and in the two populations examined (civil vs. military), that included mostly patients with 1-2 frostbite grade/degree. Two thirds of the members of the Norwegian armed forces that sustained frostbite reported suffering from sequelae until two years after the initial injury, with $21 \%$ saying that their ability to 
work and their leisure activities were negatively affected [15]. In a Swedish study, most of the patients were still suffering from long-term sequelae four years after the initial injury. $73 \%$ of patients that reported pain and discomfort in the affected tissue four months after frostbite injury had pathological findings when undergoing quantitative sensory testing (thermal and vibrotactile perception threshold) [16]. Patients treated for frostbite in the urban area of Helsinki reported suffering from chronic pain, with $15 \%$ even suffering from intolerable daily chronic pain two to nine years after the frostbite injury [17]. Another Finnish paper from Lapland reported that $63 \%$ of 30 patients treated for frostbite in the previous 4-11 years suffered from long-term sequelae [18]. 38 of 40 Norwegian soldiers who suffered from frostbite of first to third degree during their service reported chronic ailments $[19,20]$. The US army reported that $65 \%$ of inpatients treated for frostbite suffered symptoms such as cold sensitivity, paraesthesia, pain, and hyperaesthesia six months after the initial injury [21]. During the Korean war, the vast majority of US soldiers evacuated due to frostbite injury suffered from either hyperhidrosis, chronic pain, cold hypersensitivity, paraesthesia, and/or arthritis four years after injury [22].

In addition, our literature search retrieved 23 case reports and series, including 40 patients suffering from frostbite long-term sequelae (Table S1) [45,51-72]. Most of the case reports describe frostbite-related arthritis that clinically and radiologically resembles osteoarthritis. Due to the insidious symptom progression in patients suffering from frostbite arthritis, diagnosis is often delayed-sometimes for decades. Frostbite during childhood was associated with epiphyseal plate damage leading to deformities of affected fingers. Of note, ten cases of squamous cell carcinoma on the heel that developed 25 to 35 years after initial frostbite injury have been reported in Greek World War II veterans [59].

\section{Discussion}

The main findings of the present scoping review are that data about long-term sequelae from frostbite are scarce and, in many publications, patients were not followed-up for the long term. Among 493 patients from five studies in which long-term sequalae could be clearly attributed to individual patients, 341 were affected (69\%). Long-term sequelae included neuropathy-related signs and symptoms like chronic dysesthesia, chronic pain, and hyperhidrosis, often leading to functional impairment. Such long-term sequelae were common even with frostbites of first and second grade in healthy individuals. It must be noted that the definition of long-term sequalae is subject to debate since spontaneous recovery from acute injury can take several months [73]. We included studies and cases that reported sequalae that appeared after conclusion of treatment of the acute injury, regardless of the time after injury. This resulted in data from 4 months to 50 years after injury.

After frostbite lesions, vasomotor disturbances—notably vasospasm-leading to impaired circulation are associated with chronic pain and cold hypersensitivity [74]. Data from an animal model indicates that frostbite injury leads to a decrease in endothelial nitric oxide production, possibly predisposing affected tissue to vasoconstriction [75]. Furthermore, it has been proposed that higher sympathetic drive during cooling of frostbite-injured tissue may contribute to vasoconstriction and cold sensitivity [5] Cold sensitization, also termed allodynia, is caused by inflammation that lowers the threshold for pain perception, allowing innocuous stimuli to produce pain in the sensitised tissue. Chronic pain includes cold allodynia (excessive reaction to all stimuli, including those not normally evoking pain, that radiates to adjacent areas and persists beyond the stimulus), hypoesthesia (partial loss of all forms of sensation), paraesthesia (spontaneous positive, prickling sensation), hyperaesthesia (increased cutaneous sensitivity to various stimuli) and hyperhidrosis (due to overactivity of sudomotor nerve fibres), all of which have been ascribed to cold-induced nerve damage [18]. All these symptoms were variably reported in the eight studies reviewed [15-22]. In patients with freezing cold injuries, a loss of small and large neuronal fibre function has been evidenced, suggesting that pain has its origin in neuropathy [76].Indeed, Carlsson et al. documented in a series of 40 soldiers with such long-term sequelae a decrease in nerve conduction velocity (both motor and sensory), 
and an increased motor distal delay consistent with neuropathy [16]. This damage has been suggested to be due to direct cold nerve injury (e.g., from ice-crystal formation) or to retrograde axonal degeneration after peripheral axonotmesis [77]. Furthermore, patients with long-term sequelae have shown a heavily delayed or abolished Hunting reaction in the affected tissue [78]. At the same time, they were prone to vasospasm and had a pronounced decrease in skin temperature upon exposure to cold air [18]. In a rat model, partial freezing of the sciatic nerve has induced transient thermal hyperalgesia, while complete freezing led to anaesthesia [79]. Transient receptor potential cation channel, subfamily $\mathrm{M}$, member 8 (TRPM8) is an excitatory ion channel expressed on A $\delta$ and C-fibres, which is activated at temperatures $<20^{\circ} \mathrm{C}$ [80-83] (Figure 3).

It has been shown that menthol topical application induced cold allodynia via activation and sensitisation of TRPM8 (being both a menthol and cold-sensitive ion channel) $[81,82]$. It is thought to be the main detector of environmental cold in mice and is part of the transient receptor potential channel (TRP) family, which also includes TRPA1 and TRPV2 [84-87]. TRPA1 is expressed on C-fibres and is also activated by noxious cold $\left(5-18{ }^{\circ} \mathrm{C}\right)$ [88]. In contrast, TRPV2 is found on larger and myelinated sensory $\mathrm{A} \beta$ - and A $\delta$-fibres and is activated upon heat $\left(>52^{\circ} \mathrm{C}\right)$ [89]. Furthermore, TRPA 1 and TRPM 8 act as mediators for vasoconstriction upon tissue cooling [90]. The sciatic nerve chronic constriction injury (CCI) rat model is widely used to study peripheral nerve injury [91,92]. Frederick at al. reported that TRPA1, TRPM8, and TRPV2 expression was upregulated in the ipsilateral dorsal root ganglia of L4-L6 after sciatic nerve CCI [93]. These findings suggest that freezing-induced peripheral nerve damage and subsequent upregulation of the beforementioned receptors play a role in frostbite-induced temperature hypersensitivity. Accordingly, Su et al. found elevated TRPM8 protein levels in the ipsilateral L5 ganglion and reported that rats suffered from cold allodynia after sciatic nerve CCI [94]. Intrathecal administration of TRPM8 antisense oligonucleotides attenuated cold allodynia and decreased TRPM8 protein levels. Calvo et al. also showed that TRPM8 antagonists are effective against cold allodynia in rats [95]. However, Namer et al. reported that topical administration of a $20 \%$ cinnamaldehyde (TRPA1 agonist) or a $40 \%$ menthol (TRPM8 agonist) solution on patients suffering from frostbite-related cold allodynia did not show any sensitisation compared to healthy controls, suggesting that cold allodynia in these patients is not related to the overexpression of these receptors [96]. Thus, the exact role of the TPR family in thermal hyperalgesia secondary to frostbite is still under debate and needs further investigation.

In addition, frostbite arthritis is another important sequelae found in patients with previous frostbite injury. Clinically resembling regular osteoarthritis, it usually appears month or years after the initial frostbite injury. The underlying bone and cartilage damage are thought to be mostly a consequence of circulatory insufficiency during frostbite injury, although direct cold damage may also be involved [54]. In children, the higher specific surface increases the risk of frostbite injury and severity and can lead to epiphyseal cartilage damage and subsequent abnormal growth of the affected bones $[54,56,58,60,63,70,97]$. 
(A) General anatomy of sensory $A \beta-, A \delta$ - and C-fibers

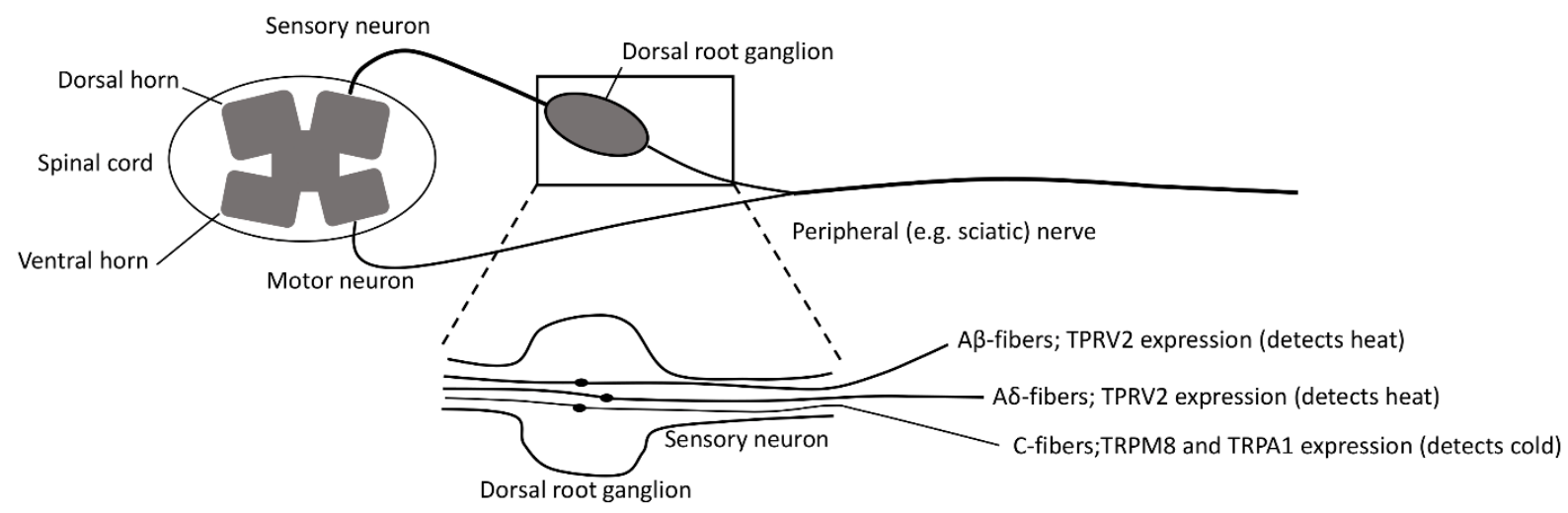

(B) Sciatic chronic contriction injury $(\mathrm{CCl})$ resulting in cold allodynia in rats

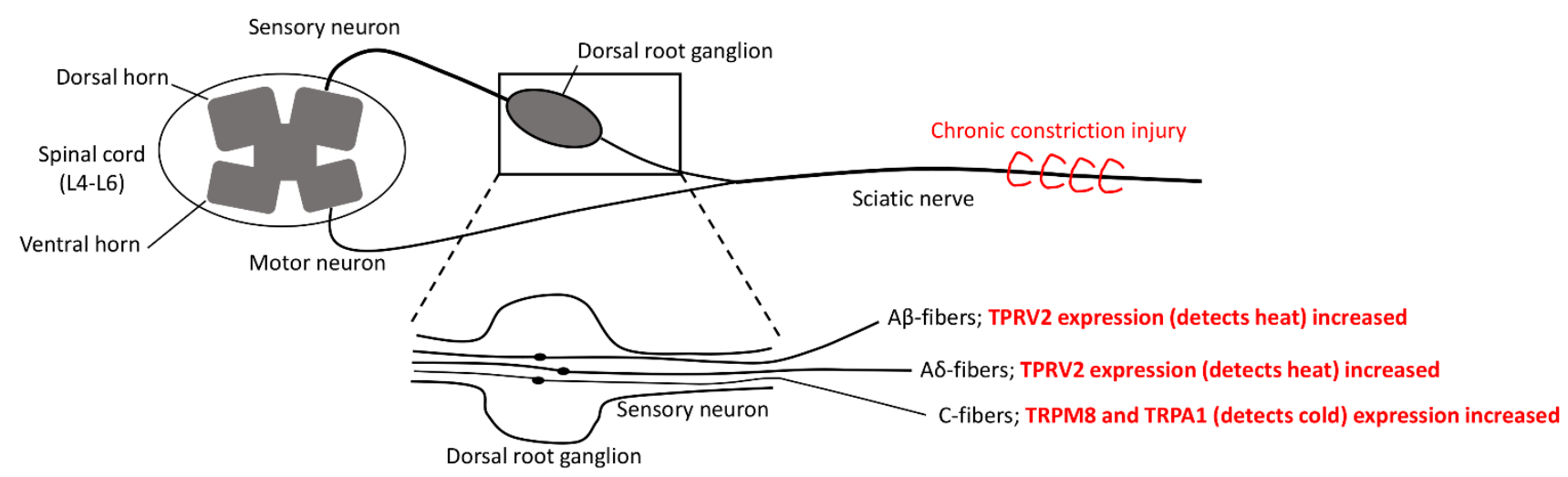

(C) Intrathecal injection of TRPM8 antisense oligonucleotide attenuates sciatic CCI induced cold allodynia in rats

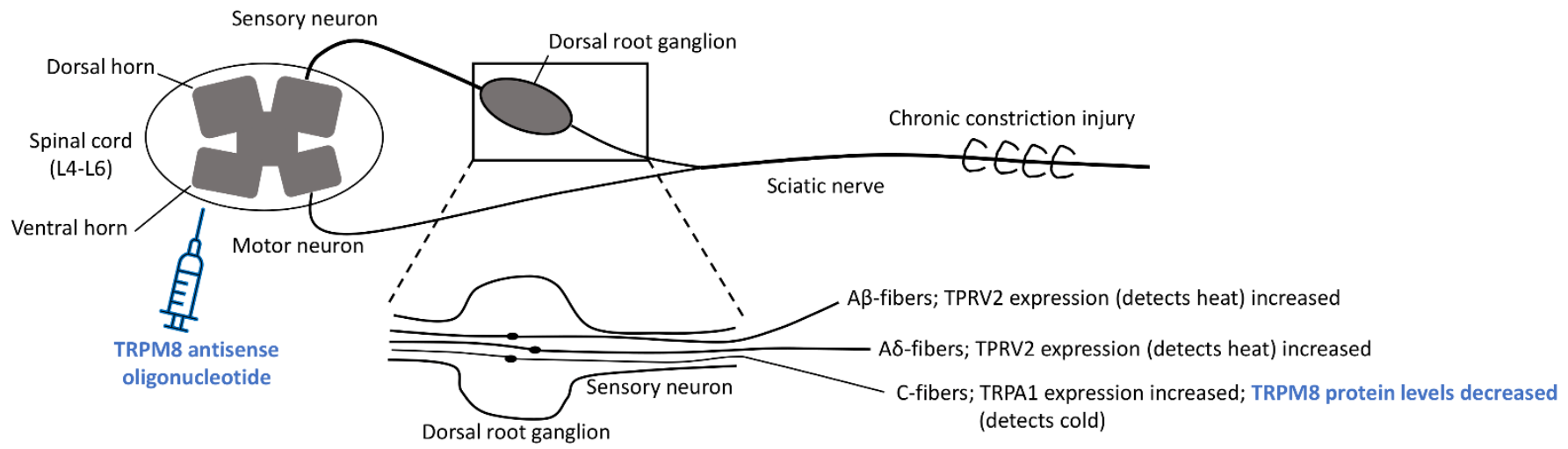

Figure 3. The role of the transient receptor potential channel (TRP) family in cold allodynia. (A) Sensory A $\beta$ - and A $\delta$-fibres express TRPV2 activated by heat stimulus $>52{ }^{\circ} \mathrm{C}$. C-fibres express TRPA 1 activated by cold $\left(5-18{ }^{\circ} \mathrm{C}\right)$ and TRPM 8 activated by cold $\left(<20^{\circ} \mathrm{C}\right)$. (B) During sciatic CCI, cold allodynia was associated with expression of TRPV2, TRPA1, and TRPM8 in the ipsilateral dorsal root ganglia at L4-L6. (C) Intrathecal injection of TRPM8 antisense oligonucleotide attenuated cold allodynia and decreased TRPM8 protein levels in the ipsilateral dorsal root ganglia of L4-L6. TRPV2: Transient receptor potential cation channel, subfamily V, member 2; TRPA1: Transient receptor potential cation channel, subfamily A, member 1; TRPM8: Transient receptor potential cation channel, subfamily M, member 8; CCI: Chronic Constriction Injury; L: Lumbar vertebra. 
In many cases, the management of chronic neuropathic pain after frostbite is challenging; duloxetine, amitriptyline, and gabapentinoids such gabapentin or pregabalin might be beneficial. Also, topical administration of capsaicin or lidocaine are thought to alleviate painful frostbite sequalae $[46,47,49]$. Furthermore, epidural sympathetic blockade has been described as an effective temporary and non-destructive treatment [48]. Long-lasting sympathectomies can be achieved chemically (e.g., alcohol or phenol injection) and surgically (e.g., open removal or electrocoagulation of sympathetic chain, or minimally invasive stereotactic thermal or laser interruption) [98]. Also, surgical sympathectomy [48,74], vasodilators, and $\beta$-blockers have been reported to ameliorate symptoms [99]. Several studies reported positive effects of Botulinum toxin type A (BTX-A) injections in patients with Raynaud's phenomenon, that is characterised by inappropriate vasoconstriction in the distal extremities upon cold stimulation [100]. BTX-A blocks acetylcholine-mediated signalling to the vasculature smooth muscle, preventing vasoconstriction. In addition, it has been shown that BTX-A impedes sympathetic vasoconstriction by blocking noradrenaline vesicle exocytosis at the vascular smooth muscle neuromuscular junction in a guinea-pig model [101]. Moreover, it has been shown that BTX-A decreases the activity of C-fibre nociceptors through inhibition of the release of local nociceptive neuropeptides (e.g., calcitonin gene-related peptide, substance $\mathrm{P}$, glutamate). All these mechanisms are thought to act together, reducing cold-induced vasoconstriction and pain [101,102]. There is evidence that intradermal, subcutaneous, or perineural injection of BTX-A is useful in the treatment of chronic neuropathic pain $[103,104]$. Injection around the neurovascular bundles in the palm of frostbite-injured fingers in a patient suffering from cold hypersensitivity and sensorymotor disturbances secondary to frostbite successfully mitigated most of these symptoms in a case report [45]. In the same case, infrared thermography measurement showed that BTXA treatment did improve skin rewarming after a mild cold provocation test (which implies an improvement of perfusion), and quantitative sensory testing showed an improvement in sensory function. Frostbite arthritis patients may benefit from non-pharmacological interventions such as physiotherapy [51]. There is one report about clodronic acid having some therapeutic benefits, while non-steroidal anti-inflammatory drugs are thought to be of little benefit [53]. Due to the complexity of refractory pain after frostbite, a chronic pain specialist should be included in a multidisciplinary approach $[46,47,49]$.

\section{Limitations}

The scarcity of data on long-term sequelae of frostbite is the major limitation of this review.

\section{Conclusions}

In the 670 frostbite patients who were followed up, many suffered from long-term sequelae. These include neuropathy-related signs and symptoms (chronic dysesthesia, chronic pain, and hyperhidrosis), as well as arthritis - even after lower-grade frostbite in healthy individuals. Botulinum toxin is a promising therapeutic option for neuropathic and vasomotor difficulties that needs further research. Epidural sympathectomy is another beneficial intervention for temporary symptom relief. More in-depth research into the pathogenesis of cold allodynia and the role of the TRP family may lead to new specific treatments of neuropathic and vasomotor difficulties. The treatment of frostbite arthritis with clodronic acid has been described as useful in one case report and needs further investigation.

A better understanding of the exact injury mechanism could help to determine the extent to which it might be possible to intervene pharmacologically in a potentially chronic inflammatory process.

Supplementary Materials: The following are available online at https:/ /www.mdpi.com/article/10 .3390 /ijerph18189655/s1, Table S1: Case reports and case series about frostbite long-term sequelae. 
Author Contributions: Conceptualization, I.B.R., G.S. and H.B.; methodology, I.B.R., G.S. and H.B.; software, I.B.R.; validation, I.B.R., G.S., M.F., R.O. and H.B.; formal analysis, I.B.R.; investigation I.B.R., G.S., M.F., R.O. and H.B.; resources, G.S. and H.B.; data curation, I.B.R., G.S., M.F., R.O. and H.B.; writing—original draft preparation, I.B.R.; writing—review and editing, I.B.R., G.S., M.F., R.O. and H.B.; visualization, I.B.R.; supervision, G.S. and H.B; project administration, I.B.R.; All authors have read and agreed to the published version of the manuscript.

Funding: This review did not receive any external funding.

Institutional Review Board Statement: Not applicable.

Informed Consent Statement: Not applicable.

Acknowledgments: We thank Maria Berenice Martinez Salazar for her excellent support.

Conflicts of Interest: The authors declare no conflict of interest.

\section{References}

1. McIntosh, S.E.; Freer, L.; Grissom, C.K.; Auerbach, P.S.; Rodway, G.W.; Cochran, A.; Giesbrecht, G.G.; McDevitt, M.; Imray, C.H.; Johnson, E.L.; et al. Wilderness Medical Society Clinical Practice Guidelines for the Prevention and Treatment of Frostbite: 2019 Update. Wilderness Environ. Med. 2019, 30, S19-S32. [CrossRef]

2. Danielsson, U. Windchill and the risk of tissue freezing. J. Appl. Physiol. 1996, 81, 2666-2673. [CrossRef] [PubMed]

3. Grieve, A.W.; Davis, P.; Dhillon, S.; Richards, P.; Hillebrandt, D.; Imray, C. A Clinical Review of the Management of Frostbite. J. R. Army Med. Corps 2011, 157, 73-78. [CrossRef]

4. Imray, C.; Grieve, A.; Dhillon, S.; The Caudwell Xtreme Everest Research Group. Cold damage to the extremities: Frostbite and non-freezing cold injuries. Postgrad. Med. J. 2009, 85, 481-488. [CrossRef] [PubMed]

5. Gorjanc, J.; Morrison, S.; Blagus, R.; Mekjavić, I.B. Cold Susceptibility of Digit Stumps Resulting from Amputation After Freezing Cold Injury in Elite Alpinists. High Alt. Med. Biol. 2018, 19, 185-192. [CrossRef] [PubMed]

6. Murphy, W.A.; Dz, D.Z.N.; Gostner, P.; Knapp, R.; Recheis, W.; Seidler, H. The Iceman: Discovery and Imaging. Radiology 2003, 226, 614-629. [CrossRef]

7. Larrey, D.J.; Hall, R.W. Memoirs of Military Surgery, and Campaigns of the French Armies, on the Rhine, in Corsica, Catalonia, Egypt, and Syria; at Boulogne, Ulm, and Austerlitz; in Saxony, Prussia, Poland, Spain, and Austria; Joseph Cushing: Baltimore, MD, USA, 1814.

8. Joshi, K.; Goyary, D.; Mazumder, B.; Chattopadhyay, P.; Chakraborty, R.; Bhutia, Y.; Karmakar, S.; Dwivedi, S.K. Frostbite: Current status and advancements in therapeutics. J. Therm. Biol. 2020, 93, 102716. [CrossRef] [PubMed]

9. Handford, C.; Thomas, O.; Imray, C.H.E. Frostbite. Emerg. Med. Clin. N. Am. 2017, 35, 281-299. [CrossRef] [PubMed]

10. Valnicek, S.M.; Chasmar, L.R.; Clapson, J.B. Frostbite in the prairies: A 12-year review. Plast. Reconstr. Surg. 1993, 92, 633-641. [CrossRef]

11. Imray, C.H.E.; Oakley, E.H.N. Cold Still Kills: Cold-Related Illnesses in Military Practice Freezing and Non-Freezing Cold Injury. J. R. Army Med. Corps 2005, 151, 218-222. [CrossRef] [PubMed]

12. McIntosh, S.E.; Campbell, A.; Weber, D.; Dow, J.; Joy, E.; Grissom, C.K. Mountaineering Medical Events and Trauma on Denali, 1992-2011. High Alt. Med. Biol. 2012, 13, 275-280. [CrossRef]

13. Némethy, M.; Pressman, A.B.; Freer, L.; McIntosh, S.E. Mt Everest Base Camp Medical Clinic "Everest ER": Epidemiology of Medical Events during the First 10 Years of Operation. Wilderness Environ. Med. 2015, 26, 4-10. [CrossRef]

14. Harirchi, I.; Arvin, A.; Vash, J.H.; Zafarmand, V. Frostbite: Incidence and predisposing factors in mountaineers. Br. J. Sports Med. 2005, 39, 898-901. [CrossRef] [PubMed]

15. Norheim, A.J.; Borud, E.K. Frostbite in the Norwegian Armed Forces. Tidsskr. Nor. Legeforening 2018, 138. [CrossRef]

16. Carlsson, D.; Burström, L.; Lilliesköld, V.H.; Nilsson, T.; Nordh, E.; Wahlström, J. Neurosensory sequelae assessed by thermal and vibrotactile perception thresholds after local cold injury. Int. J. Circumpolar Health 2014, 73, 384. [CrossRef] [PubMed]

17. Koljonen, V.; Andersson, K.; Mikkonen, K.; Vuola, J. Frostbite Injuries Treated in the Helsinki Area from 1995 to 2002. J. Trauma Inj. Infect. Crit. Care 2004, 57, 1315-1320. [CrossRef]

18. Ervasti, O.; Hassi, J.; Rintamäki, H.; Virokannas, H.; Kettunen, P.; Pramila, S.; Linna, T.; Tolonen, U.; Manelius, J. Sequelae of moderate finger frostbite as assessed by subjective sensations, clinical signs, and thermophysiological responses. Int. J. Circumpolar Health 2000, 59, 137-145.

19. Arvesen, A.; Wilson, J.; Rosén, L. Nerve conduction velocity in human limbs with late sequelae after local cold injury. Eur. J. Clin. Investig. 1996, 26, 443-450. [CrossRef]

20. Rosén, L.; Eltvik, L.; Arvesen, A.; Stranden, E. Local cold injuries sustained during military service in the Norwegian Army. Arct. Med. Res. 1991, 50, 159-165.

21. Taylor, M.S.; A Kulungowski, M.; Hamelink, J.K. Frostbite injuries during winter maneuvers: A long-term disability. Mil. Med. 1989, 154, 411-412. [CrossRef]

22. Blair, J.R.; Schatzki, R.; Orr, K.D. Sequelae to cold injury in one hundred patients; follow-up study four years after occurrence of cold injury. J. Am. Med. Assoc. 1957, 163, 1203-1208. [CrossRef] [PubMed] 
23. Johnson, J.M.; Minson, C.T.; Kellogg, D.L. Cutaneous Vasodilator and Vasoconstrictor Mechanisms in Temperature Regulation. Compr. Physiol. 2014, 4, 33-89. [CrossRef] [PubMed]

24. Dana, A.S., Jr.; Rex, I.H., Jr.; Samitz, M.H. The Hunting Reaction. Arch. Dermatol. 1969, 99, 441-450. [CrossRef] [PubMed]

25. Wilson, O.; Goldman, R.F. Role of air temperature and wind in the time necessary for a finger to freeze. J. Appl. Physiol. 1970, 29, 658-664. [CrossRef] [PubMed]

26. Heggers, J.P.; Robson, M.C.; Manavalen, K.; Weingarten, M.D.; Carethers, J.M.; A Boertman, J.; Smith, D.J.; Sachs, R.J. Experimental and clinical observations on frostbite. Ann. Emerg. Med. 1987, 16, 1056-1062. [CrossRef]

27. Mazur, P. Cryobiology: The Freezing of Biological Systems. Science 1970, 168, 939-949. [CrossRef]

28. Meryman, H.; Williams, R.; Douglas, M. Freezing injury from "solution effects" and its prevention by natural or artificial cryoprotection. Cryobiology 1977, 14, 287-302. [CrossRef]

29. Mazur, P. Causes of injury in frozen and thawed cells. Fed. Proc. 1965, 24, S175-S182.

30. Manson, P.; Jesudass, R.; Marzella, L.; Bulkley, G.; Im, M.; Narayan, K. Evidence for an early free radical-mediated reperfusion injury in frostbite. Free Radic. Biol. Med. 1991, 10, 7-11. [CrossRef]

31. Nakae, H.; Endo, S.; Inada, K.; Yamashita, H.; Yamada, Y.; Takakuwa, T.; Kasai, T.; Ogawa, M.; Uchida, K. Plasma concentrations of type II phospholipase A2, cytokines and eicosanoids in patients with burns. Burns 1995, 21, 422-426. [CrossRef]

32. Huribal, M.; E Cunningham, M.; D'Aiuto, M.L.; E Pleban, W.; A McMillen, M. Endothelin-1 and prostaglandin E2 levels increase in patients with burns. J. Am. Coll. Surg. 1995, 180, 318-322.

33. Harms, B.A.; Bodai, B.I.; Smith, M.; Gunther, R.; Flynn, J.; Demling, R.H. Prostaglandin release and altered microvascular integrity after burn injury. J. Surg. Res. 1981, 31, 274-280. [CrossRef]

34. Robson, M.C.; Del Beccaro, E.J.; Heggers, J.P. The effect of prostaglandins on the dermal microcirculation after burning, and the inhibition of the effect by specific pharmacological agents. Plast. Reconstr. Surg. 1979, 63, 781-787. [CrossRef]

35. Back, N.; Jainchill, M.; Wilkens, H.; Ambrus, J. Effect of Inhibitors of Plasmin, Kallikrein and Kinin on Mortality from Scalding in Mice. Pharmacology 1966, 15, 597-602. [CrossRef]

36. Tanaka, H.; Wada, T.; Simazaki, S.; Hanumadass, M.; Reyes, H.M.; Matsuda, T. Effects of Cimetidine on Fluid Requirement During Resuscitation of Third-Degree Burns. J. Burn Care Rehabil. 1991, 12, 425-429. [CrossRef]

37. Alexander, F.; Mathieson, M.; Teoh, K.H.T.; Huval, W.V.; Lelcuk, S.; Valeri, C.R.; Shepro, D.; Hechtman, H.B. Arachidonic Acid Metabolites Mediate Early Burn Edema. J. Trauma Inj. Infect. Crit. Care 1984, 24, 709-712. [CrossRef]

38. Jackson, D.M. The diagnosis of the depth of burning. BJS 2005, 40, 588-596. [CrossRef]

39. Robson, M.C.; Heggers, J.P. Evaluation of hand frostbite blister fluid as a clue to pathogenesis. J. Hand Surg. 1981, 6, 43-47. [CrossRef]

40. Heggers, J.P.; Ko, F.; Robson, M.C.; Heggers, R.; Craft, K.E. Evaluation of Burn Blister Fluid. Plast. Reconstr. Surg. 1980, 65, 798-804. [CrossRef]

41. Cauchy, E.; Chetaille, E.; Marchand, V.; Marsigny, B. Retrospective study of 70 cases of severe frostbite lesions: A proposed new classification scheme. Wilderness Environ. Med. 2001, 12, 248-255. [CrossRef]

42. Mills, W.J., Jr. Clinical Aspects of Freezing Cold Injuries. In Medical Aspects of Harsh Environments; Office of the Surgeon General ; Department of the Army, United States of America: Falls Church, VA, USA, 2001; 35, pp. 429-466.

43. Lorentzen, A.K.; Davis, C.; Penninga, L. Interventions for frostbite injuries. Cochrane Database Syst. Rev. 2020, 12, CD012980. [CrossRef]

44. Zhang, X.-H.; Cui, C.-L.; Zhu, H.-Y.; Wang, J.; Xue, Y.; Zhang, N.; Sun, Z.-A.; Gao, X.-X.; Zhou, X.; Yu, J.-A.; et al. The Effects of Recombinant Human Granulocyte-Macrophage Colony-Stimulating Factor Gel on Third-Degree Frostbite Wounds in Northeastern China: A Randomized Controlled Trial. J. Burn Care Res. 2020. [CrossRef] [PubMed]

45. Norheim, A.J.; Mercer, J.; Musial, F.; De Weerd, L. A new treatment for frostbite sequelae; Botulinum toxin. Int. J. Circumpolar Health 2017, 76, 1273677. [CrossRef] [PubMed]

46. Handford, C.; Buxton, P.; Russell, K.; Imray, C.E.; E McIntosh, S.; Freer, L.; Cochran, A.; Imray, C.H. Frostbite: A practical approach to hospital management. Extreme Physiol. Med. 2014, 3, 7. [CrossRef]

47. Bates, D.; Schultheis, B.C.; Hanes, M.C.; Jolly, S.M.; Chakravarthy, K.V.; Deer, T.R.; Levy, R.M.; Hunter, C.W. A Comprehensive Algorithm for Management of Neuropathic Pain. Pain Med. 2019, 20, S2-S12. [CrossRef]

48. Taylor, M.S. Lumbar Epidural Sympathectomy for Frostbite Injuries of the Feet. Mil. Med. 1999, 164, 566-567. [CrossRef]

49. Finnerup, N.B.; Kuner, R.; Jensen, T.S. Neuropathic pain: From mechanisms to treatment. Physiol. Rev. 2021, 101, 259-301. [CrossRef] [PubMed]

50. Tricco, A.C. PRISMA Extension for Scoping Reviews (PRISMA-ScR): Checklist and Explanation. Ann. Intern. Med. 2018, 169, 467-473. [CrossRef]

51. Irsay, L.; Ungur, R.A.; Borda, I.M.; Ciubean, A.D.; Moldovan, I.; Trăistaru, M.R.; Kamal, K.C.; Kamal, D.; Ciortea, V.M. Frostbite arthropathy-A rare case of osteoarthritis, review of the literature and case presentation. Rom. J. Morphol. Embryol. 2019, 60, 1337-1341. [PubMed]

52. Wang, Y.; Saad, E.; Bonife, T.; Wainapel, S.F. Frostbite Arthritis. Am. J. Phys. Med. Rehabil. 2016, 95, e28. [CrossRef] [PubMed]

53. E Kahn, J.; Lidove, O.; Laredo, J.D.; Blétry, O. Frostbite arthritis. Ann. Rheum. Dis. 2005, 64, 966-967. [CrossRef]

54. Pettit, M.T.; Finger, D.R. Frostbite arthropathy. J. Clin. Rheumatol. 1998, 4, 316-318. [PubMed]

55. Turner, M.; Smith, R.W. Unusual and memorable. Erosive nodal osteoarthritis after frostbite. Ann. Rheum. Dis. 1998, 57, 271. 
56. Crouch, C.; Smith, W.L. Long term sequelae of frostbite. Pediatr. Radiol. 1990, 20, 365-366. [CrossRef] [PubMed]

57. Leung, A.K.; Lai, P.C. Digital deformities from frostbite. Can. Med. Assoc. J. 1985, 132, 14-15. [PubMed]

58. Nakazato, T.; Ogino, T. Epiphyseal destruction of children's hands after frostbite: A report of two cases. J. Hand Surg. Am. 1986, 11, 289-292. [CrossRef]

59. Rossis, C.G.; Yiacoumettis, A.M.; Elemenoglou, J. Squamous cell carcinoma of the heel developing at site of previous frostbite1. J. R. Soc. Med. 1982, 75, 715-718.

60. Carrera, G.F.; Kozin, F.; Flaherty, L.; Mccarty, D.J. Radiographic changes in the hands following childhood frostbite injury. Skelet. Radiol. 1981, 6, 33-37. [CrossRef]

61. McKendry, R.J. Frostbite arthritis. Can. Med. Assoc. J. 1981, 125, 1128-1130.

62. Solomon, S.D. Frostbite arthritis. Arthritis Rheum. 1980, 23, 1332. [CrossRef]

63. Carrera, G.F.; Kozin, F.; Mccarty, D.J. Arthritis after frostbite injury in children. Arthritis Rheum. 1979, 22, 1082-1087. [CrossRef]

64. Ellis, R.; Short, J.G.; Simonds, B.D. Unilateral osteoarthritis of the distal interphalangeal joints following frostbite: A case report. Radiology 1969, 93, 857-858. [CrossRef] [PubMed]

65. Selke, A.C. Destruction of Phalangeal Epiphyses by Frostbite. Radiology 1969, 93, 859-860. [CrossRef] [PubMed]

66. Lindholm, A.; Nilsson, O.; Svartholm, F. Epiphyseal destruction following frostbite. Report of three cases. Acta Chir. Scand. 1968, 134, 37-40. [PubMed]

67. Wenzl, J.E.; Burke, E.C.; Bianco, A.J., Jr. Epiphyseal destruction from frostbite of the hands. Am. J. Dis. Child. 1967, 114, 668-670. [CrossRef]

68. Bigelow, D.R.; Ritchie, G.W. The effects of frostbite in childhood. J. Bone Jt. Surg. Br. Vol. 1963, 45-B, 122-131. [CrossRef]

69. Florkiewicz, L.; Kozlowski, K. Symmetrical Epiphyseal Destruction by Frostbite. Arch. Dis. Child. 1962, 37, 51-52. [CrossRef]

70. Dreyfuss, J.R.; Glimcher, M.J. Epiphyseal Injury Following Frostbite. N. Engl. J. Med. 1955, 253, 1065-1068. [CrossRef]

71. Thelander, H. Epiphyseal destruction by frostbite. J. Pediatr. 1950, 36, 105-106. [CrossRef]

72. Bennett, R.B.; Blount, W.P. Destruction of epiphyses by freezing. JAMA 1935, 105, 661-662. [CrossRef]

73. Murphy, J.V.; Banwell, P.E.; Roberts, A.H.N.; McGrouther, D.A. Frostbite: Pathogenesis and Treatment. J. Trauma Inj. Infect. Crit. Care 2000, 48, 171-178. [CrossRef]

74. Khan, M.I.; Tariq, M.; Rehman, A.; Zafar, A.; Sheen, S.N. Efficacy of cervicothoracic sympathectomy versus conservative management in patients suffering from incapacitating Raynaud's syndrome after frost bite. J. Ayub. Med. Coll. Abbottabad. 2008, 20, 21-24.

75. Tercan, M.; Bekerecioglu, M. Decreased Serum Nitric Oxide Level in Experimental Frostbite Injury: A Preliminary Study. Ann. Plast. Surg. 2002, 48, 107-108. [CrossRef]

76. Finnerup, N.B.; Haroutounian, S.; Kamerman, P.; Baron, R.; Bennett, D.; Bouhassira, D.; Cruccu, G.; Freeman, R.; Hansson, P.; Nurmikko, T.; et al. Neuropathic pain: An updated grading system for research and clinical practice. Pain 2016, 157, $1599-1606$. [CrossRef] [PubMed]

77. Mumenthaler, M.; Schliack, H.; Eichenberger, M. Läsionen Peripherer Nerven: Diagnostik und Therapie; Thieme-Verlag: New York, NY, USA, 1977; ISBN 10:3133802038.

78. Arvesen, A.; Rosén, L.; Eltvik, L.P.; Kroese, A.; Stranden, E. Skin microcirculation in patients with sequelae from local cold injuries. Int. J. Microcirc. 1994, 14, 335-342. [CrossRef] [PubMed]

79. Myers, R.R.; Heckman, H.M.; Powell, H.C. Axonal viability and the persistence of thermal hyperalgesia after partial freeze lesions of nerve. J. Neurol. Sci. 1996, 139, 28-38. [CrossRef]

80. Kobayashi, K.; Fukuoka, T.; Obata, K.; Yamanaka, H.; Dai, Y.; Tokunaga, A.; Noguchi, K. Distinct expression of TRPM8, TRPA1, and TRPV1 mRNAs in rat primary afferent neurons with adelta/c-fibers and colocalization with trk receptors. J. Comp. Neurol. 2005, 493, 596-606. [CrossRef]

81. McKemy, D.D.; Neuhausser, W.M.; Julius, D. Identification of a cold receptor reveals a general role for TRP channels in thermosensation. Nat. Cell Biol. 2002, 416, 52-58. [CrossRef]

82. Peier, A.M.; Moqrich, A.; Hergarden, A.C.; Reeve, A.J.; Andersson, D.; Story, G.M.; Earley, T.J.; Dragoni, I.; McIntyre, P.; Bevan, S.J.; et al. A TRP Channel that Senses Cold Stimuli and Menthol. Cell 2002, 108, 705-715. [CrossRef]

83. Wasner, G.; Schattschneider, J.; Binder, A.; Baron, R. Topical menthol-a human model for cold pain by activation and sensitization of C nociceptors. Brain 2004, 127, 1159-1171. [CrossRef]

84. Bautista, D.M.; Siemens, J.; Glazer, J.M.; Tsuruda, P.R.; Basbaum, A.I.; Stucky, C.L.; Jordt, S.-E.; Julius, D. The menthol receptor TRPM8 is the principal detector of environmental cold. Nat. Cell Biol. 2007, 448, 204-208. [CrossRef]

85. Colburn, R.W.; Lubin, M.L.; Stone, D.J.; Wang, Y.; Lawrence, D.; D’Andrea, M.R.; Brandt, M.R.; Liu, Y.; Flores, C.M.; Qin, N. Attenuated Cold Sensitivity in TRPM8 Null Mice. Neuron 2007, 54, 379-386. [CrossRef]

86. Dhaka, A.; Murray, A.N.; Mathur, J.; Earley, T.J.; Petrus, M.J.; Patapoutian, A. TRPM8 Is Required for Cold Sensation in Mice. Neuron 2007, 54, 371-378. [CrossRef] [PubMed]

87. Knowlton, W.M.; Palkar, R.; Lippoldt, E.K.; McCoy, D.D.; Baluch, F.; Chen, J.; McKemy, D.D. A Sensory-Labeled Line for Cold: TRPM8-Expressing Sensory Neurons Define the Cellular Basis for Cold, Cold Pain, and Cooling-Mediated Analgesia. J. Neurosci. 2013, 33, 2837-2848. [CrossRef] [PubMed]

88. Sawada, Y.; Hosokawa, H.; Hori, A.; Matsumura, K.; Kobayashi, S. Cold sensitivity of recombinant TRPA1 channels. Brain Res. 2007, 1160, 39-46. [CrossRef] [PubMed] 
89. Shibasaki, K. Physiological significance of TRPV2 as a mechanosensor, thermosensor and lipid sensor. J. Physiol. Sci. 2016, 66, 359-365. [CrossRef] [PubMed]

90. Pan, Y.; Thapa, D.; Baldissera, L.; Argunhan, F.; Aubdool, A.; Brain, S.D. Relevance of TRPA1 and TRPM8 channels as vascular sensors of cold in the cutaneous microvasculature. Pflügers Archiv-Eur. J. Physiol. 2018, 470, 779-786. [CrossRef]

91. Austin, P.; Wu, A.; Moalem-Taylor, G. Chronic Constriction of the Sciatic Nerve and Pain Hypersensitivity Testing in Rats. J. Vis. Exp. 2012, 2012, e3393. [CrossRef]

92. Bennett, G.J.; Xie, Y.-K. A peripheral mononeuropathy in rat that produces disorders of pain sensation like those seen in man. Pain 1988, 33, 87-107. [CrossRef]

93. Frederick, J.; Buck, M.; Matson, D.; Cortright, D. Increased TRPA1, TRPM8, and TRPV2 expression in dorsal root ganglia by nerve injury. Biochem. Biophys. Res. Commun. 2007, 358, 1058-1064. [CrossRef]

94. Su, L.; Wang, C.; Yu, Y.-H.; Ren, Y.-Y.; Xie, K.-L.; Wang, G.-L. Role of TRPM8 in dorsal root ganglion in nerve injury-induced chronic pain. BMC Neurosci. 2011, 12, 120. [CrossRef] [PubMed]

95. Calvo, R.R.; Meegalla, S.K.; Parks, D.J.; Parsons, W.H.; Ballentine, S.K.; Lubin, M.L.; Schneider, C.; Colburn, R.W.; Flores, C.M.; Player, M.R. Discovery of vinylcycloalkyl-substituted benzimidazole TRPM8 antagonists effective in the treatment of cold allodynia. Bioorg. Med. Chem. Lett. 2012, 22, 1903-1907. [CrossRef] [PubMed]

96. Namer, B.; Kleggetveit, I.P.; Handwerker, H.; Schmelz, M.; Jorum, E. Role of TRPM8 and TRPA1 for cold allodynia in patients with cold injury. Pain 2008, 139, 63-72. [CrossRef]

97. E Brown, F.; Spiegel, P.K.; E Boyle, W. Digital deformity: An effect of frostbite in children. Pediatrics 1983, 71, 955-959.

98. Jackson, T.P.; Gaeta, R. Neurolytic blocks revisited. Curr. Pain Headache Rep. 2008, 12, 7-13. [CrossRef]

99. Golant, A.; Nord, R.M.; Paksima, N.; Posner, M.A. Cold Exposure Injuries to the Extremities. J. Am. Acad. Orthop. Surg. 2008, 16, 704-715. [CrossRef]

100. Iorio, M.L.; Masden, D.L.; Higgins, J.P. Botulinum toxin A treatment of Raynaud's phenomenon: A review. Semin. Arthritis Rheum. 2012, 41, 599-603. [CrossRef]

101. Morris, J.L.; Jobling, P.; Gibbins, I.L. Differential inhibition by botulinum neurotoxin A of cotransmitters released from autonomic vasodilator neurons. Am. J. Physiol. Circ. Physiol. 2001, 281, H2124-H2132. [CrossRef]

102. Neumeister, M.W.; Chambers, C.B.; Herron, M.S.; Webb, K.; Wietfeldt, J.; Gillespie, J.N.; Bueno, R.A.; Cooney, C.M. Botox Therapy for Ischemic Digits. Plast. Reconstr. Surg. 2009, 124, 191-201. [CrossRef] [PubMed]

103. Fabregat, G.; De Andrés, J.; Villanueva-Pérez, V.L.; Asensio-Samper, J.M. Subcutaneous and perineural botulinum toxin type a for neuropathic pain: A descriptive review. Clin. J. Pain 2013, 29, 1006-1012. [CrossRef] [PubMed]

104. Ranoux, D.; Attal, N.; Morain, F.; Bouhassira, D. Botulinum toxin type a induces direct analgesic effects in chronic neuropathic pain. Ann. Neurol. 2008, 64, 274-283. [CrossRef] [PubMed] 